\title{
Paweł Grad, O pojęciu tradycji: studium kryłyczne kultury pamięci, Fundacja Augusta hrabiego Cieszkowskiego, Warszawa 2017, ss. 278
}

DOI: http://dx.doi.org/10.12775/RF.2017.019

W książce O pojęciu tradycji Paweł Grad pisze o różnych sposobach odnoszenia się do historii. Modeluje on dwa podejścia: tradycję w rozumieniu właściwym oraz kulturę pamięci, która jest charakterystyczna dla postmodernistycznego, nihilistycznego konserwatyzmu. Według diagnozy autora mamy obecnie do czynienia z dominacją kultury pamięci, która polega na instrumentalnym wykorzystywaniu historii w celu legitymizowania nowoczesności. Podstawowa różnica pomiędzy takim podejściem a prawdziwą tradycją przejawia się $\mathrm{w}$ wymiarze praktycznym: dla kultury pamięci przeszłość stanowi „estetyzujące wspomnienie” i źródło inspiracji, natomiast tradycję cechuje "normatywne powtórzenie" - stanowi ona "system komunikacji służący wyodrębnieniu określonej formy życia, która realizuje się w konkretnych praktykach" (s. 11). Tym, co wyróżnia tradycję, jest zatem odrzucona przez kulturę pamięci ortopraksja - przestrzeganie reguł właściwego działania.

W pierwszym rozdziale Grad przedstawia historię pojęcia tradycji: od średniowiecznej debaty teologicznej do znaczenia ponowoczesnego. Omawiając pochodzenie tego pojęcia, wskazuje on na kilka istotnych kwestii. Przede wszystkim tradycja nie była początkowo łączona z dawnością - dla Ojców Kościoła liczył się autorytet stojący za daną tradycja, a nie to, jak długą historią mogła się ona poszczycić. Ciekawe jest również zwrócenie przez autora uwagi na ścisły związek leksykalny między pojęciami tradycji i doktryny. Doktryna stanowi ,jedno z wcieleń" tradycji. Rozumiana jest ona jako „nauka przekazana w formie imperatywu, by zachować ją niezmienioną". Wraz z towarzysząca jej dyscyplina, czyli "techniką wdrażania” danej nauki, doktryna ma służyć odróżnieniu danej wspólnoty i zachowaniu jej ciągłości (s. 25).

Ze względu na swój doktrynalny charakter tradycja stanowi swoistą historię sporów. Ten polemiczny wymiar cechował tradycję chrześcijańską od samego początku i odgrywał wielkie znaczenie w okresie reformacji. W czasie rewolucji francuskiej pojęcie to zostało znacznie rozsze- 
rzone i wykorzystane jako synonim programu kontrrewolucyjnego. We wczesnej nowoczesności tradycja oznaczać zaczęła dziedziczone przekonania i praktyki, przeciwstawione "rozumnie” wybieranym poglądom i historycznemu postępowi. Ponowoczesność zaś przyniosła dalsze przekształcenia, które doprowadziły do ujęcia tradycji bardzo ogólnie, jako „,zzegoś z przeszłości”. Jak przekonuje Grad, mamy tu do czynienia $\mathrm{z}$ przeniesieniem akcentu $\mathrm{z}$ treści doktryny na sam fakt jej dawności.

Rozdział drugi poświęcony jest nihilistycznemu konserwatyzmowi. Reprezentatywnym przykładem takiego ujęcia ma być filozofia Edmunda Burke'a, dla którego tradycja stanowi „estetyczny stabilizator postępu, który wspomaga omylny rozum „nieomylnym instynktem” tego, co dawne" (s. 39). Zdaniem Grada konserwatyzm nihilistyczny stanowi dominującą perspektywę nowoczesności i jej właściwy sens. Lokalizuje on jego początki w idei „moralności tymczasowej” Kartezjusza, która stanowiła oparcie dla metodycznie wątpiącego podmiotu, a także w ,teorii automatu" Blaise’a Pascala, wynikającej z jego słynnego zakładu i skłaniającej do zachowywania się tak, jakby wierzyło się w Boga. Oba te podejścia stanowią według Grada próbę rozwiązania problemu braku dostatecznego uzasadnienia dla zastanej wiedzy. Przejawiają tym samym podstawową cechę konserwatyzmu nihilistycznego: tradycja traktowana jest tu jako irracjonalna, niepozwalająca się rozumowo uzasadnić. Socjologia również przyjmuje perspektywę konserwatyzmu nihilistycznego, sprawiając, że wskazane wyżej rozumienie tradycji stało się rozumieniem powszechnie obowiązującym na polu nauk społecznych. Jak przekonuje Grad, jest to ujęcie nieadekwatne. Prowadzi ono bowiem do funkcjonalistycznej racjonalizacji tradycji.

Alternatywa wobec konserwatyzmu nihilistycznego została przedstawiona w rozdziale trzecim. Autor proponuje, aby myśleć o tradycji jak o systemie komunikacji. Polemizując z Jürgenem Habermasem, twierdzi on, że "logika działania komunikacyjnego właściwego tradycji opiera się na językowym utwierdzaniu i prezentacji różnicy między wspólnotą danej tradycji a otaczającym ją środowiskiem" (s. 77). Odrzucona zostaje tu idea uniwersalnej wspólnoty komunikacyjnej, konstytutywna zaś dla tradycji staje się „reguła różnicy” - nakaz jasnego i publicznego prezentowania granic danej wspólnoty tradycji. Jak przekonuje Grad: „jawny ekskluzywizm [tradycji] stanowi maksymalizację potencjału racjonalności" (s. 89), przy czym racjonalność rozumiana jest przez Grada za Robertem Brandomem jako „umiejętność posługiwania się materialnymi przesłankami w sposób, który respektuje reguły inferencji" (s. 92).

Włączenie $\mathrm{w}$ obręb wspólnoty ogranicza konwertycie możliwość wyboru poglądów sprzecznych z doktryną, w zamian jednak może on korzystać z „zestawu przesłanek, który służy mu jako baza inferencyjna przy analizowaniu i opisywaniu jego działań" (s. 85). Co więcej, uzyskuje on dostęp do praktyk danej tradycji. Innymi słowy, neofita nabywa 
„prawa" do korzystania z zasobów tradycji pod warunkiem, że będzie jej wierny. W konsekwencji wewnątrz wspólnoty możliwa jest komunikacja oparta na podzielanych przez wszystkich jej członków przesłankach. Z kolei w przestrzeni publicznej komunikacja musi zostać przełożona na „język uniwersalny”. Służy ona tutaj zabezpieczaniu pokojowego współistnienia różnych grup, ochronie ich interesów, umożliwiając ewentualne nawrócenie innych uczestników debaty. Przynależność do danej wspólnoty uwalnia zatem jej członków od konieczności ciągłego rozważania różnych alternatywnych form życia. Dialog prowadzony na zewnątrz wspólnoty przybiera jedynie ograniczoną formę, podszyty jest rywalizacja, a nawet konfliktem.

W rozdziale czwartym autor konfrontuje ze sobą dwa typy stosunku do przyszłości: historię oraz tradycję. Analizując spór między katolikami a protestantami dotyczący dostępu do źródła wiary, Grad wskazuje na fundamentalną różnicę, która dzieli te dwie gałęzie chrześcijaństwa. Dla reformacji liczy się „powtórzenie doświadczenia pierwotnego dzięki odpowiedniemu nastawieniu wewnętrznemu", dla kontrreformacyjnego katolicyzmu zaś „powtórzenie pierwotnej formy życia, składającej się ze zbioru wzajemnie komplementarnych przekonań i praktyk" (s. 137). Krótko mówiąc, protestanci twierdza, że wystarczy samo Pismo, a katolicy, że konieczne jest i Pismo, i Tradycja. Zdaniem Grada te dwa stanowiska przybierają współcześnie bądź to formę konserwatyzmu nihilistycznego, bądź tradycji rozumianej jako system komunikacji.

Kolejny rozdział poświęcony jest pytaniu o przedmiot tradycji. Grad podkreśla istnienie różnicy między kulturą pamięci a tradycją wskazując na paradygmatyczne przedmioty historyczne dla obu tych podejść - są to obiekt muzealny oraz relikwie. Podejście nowoczesne widzi w przeszłości ruinę - jest ona już nieobecna, utracona, ale może stanowić źródło inspiracji, oddziałując na wyobraźnię. Nie ma tu miejsca na odbudowę ruin, nowoczesny sens tradycji zasadza się na jej bezużyteczności. Relikwia z kolei nie daje się zamknąć w minionej przeszłości, gdyż wciąż pozostaje aktywna. Jak pisze Grad, stanowi ona „iterowalną prezentację czegoś zawsze obecnego" (s. 180). Relikwie stanowią część sieci praktyk i wierzeń, świadczą o ich skuteczności i wspierają ich odnawianie. Dawność przedmiotu nie ma przy tym znaczenia. Liczy się regularność formy życia, która stoi za przedmiotem uznawanym za relikwię.

Analizę przedmiotu tradycji dopełnia analiza jej podmiotu, zawarta $\mathrm{w}$ rozdziale szóstym. Pytanie o podmiot kultury pamięci wiąże się nieuchronnie, zdaniem autora, z problemem tożsamości. W ujęciu nowoczesnym jednostka sama ustanawia swoją tożsamość, tożsamości tej jednak stale grozi dezintegracja. Kryzys jest nierozerwanie związany z tożsamością. Tożsamość zbiorowa z kolei okazuje się fikcją gdyż wytwarzany przez nią podmiot stanowi „wspólnota wyobrażona” (s. 197). 
Podmiot tradycji stoi w opozycji wobec podmiotu kultury pamięci, który pojmowany jest indywidualistycznie i woluntarystycznie. Na gruncie tradycji w ogóle nie można mówić o podmiocie w rozumieniu Kantowskim, gdyż jej podmiot jest ponadindywidualny. Świadomość autonomicznego podmiotu zostaje tu zastąpiona przez jawność autonomicznej tradycji, przekraczającej indywidualną biografię i stanowiącej ustaloną formę, do której należy się dostosować. Relacja użytkownika względem tradycji jest niesymetryczna, gdyż sprzeniewierzenie się autorytetowi tradycji może skutkować opuszczeniem wspólnoty. Jednocześnie autor książki $O$ pojęciu tradycji podkreśla normatywny charakter tradycji przede wszystkim liczy się tu przestrzeganie reguł działania, a nie towarzysząca im narracja.

Ostatni rozdział jest poświęcony „formie życia”. Tradycja przedstawiona jest tu jako to, co nadaje życiu formę. Stanowi ona, jak pisze Grad: „system wyróżnionych praktyk i przekonań, którego głównym celem jest normalizacja, nadanie kształtu, uregulowanie strumienia codziennych i naturalnych przekonań oraz działań - praktyk i poglądów, których zazwyczaj nie uzasadniamy lub uzasadniamy je mimochodem" (s. 217). Życie bez tradycji jest konsekwentnie życiem pozbawionym formy czy kształtu - życiem nagim. Dopiero tradycja pozwala na realizację potencjalności naszego życia, czyli osiągnięcie doskonałości. Problemem, który napotyka tradycja w przestrzeni publicznej jest, według autora, niechęć nowoczesności względem zdefiniowanych form życia. W pozostałej części rozdziału autor analizuje historię pojęcia podmiotu i stara się "odebrać pojęcie formy życia Agambenowi i innym nihilistom" (s. 223), wracając do ujęcia Arystotelesa.

W Zakończeniu Grad dyskutuje metapolityczne konsekwencje swojej propozycji, sygnalizując jej pokrewieństwo z teorią sporu tradycji intelektualnych Alasdaira MacIntyre'a przywołaną w rozdziale trzecim. Spór pomiędzy różnymi uczestnikami debaty politycznej postrzegany jest tu jako środek do maksymalizacji potencjału racjonalności. Mamy więc do czynienia z koncepcją agonistyczną. Polityka stanowi walkę między różnymi tradycjami i innymi formacjami intelektualnymi, które starają się zaprezentować wyższość swojego opisu życia, przy zachowaniu minimalnych warunków translacji, sprowadzających się do zasady zachowania bytu społecznego. Nie ma tu miejsca na realny kompromis ani uzgodnienie wspólnego stanowiska.

Książka Grada jest bez wątpienia interesująca i potrzebna. Dokonuje on sprawnej analizy pojęcia tradycji i porządkuje dotyczący jej dyskurs. Czytelnik otrzymuje spójną definicję tradycji, która stanowi dobre narzędzie do dalszych badań. Jasno i wyraźnie rozdzielona zostaje tradycja 
od nowoczesnego podejścia do przeszłości - kultury pamięci, którą autor przekonująco krytykuje. O ile jednak modele są czytelne, wątpliwości wzbudza to, co ma za nimi stać. Autor analizuje wyłącznie tradycję chrześcijańską i przenosi wnioski na tradycję w ogóle, nie uzasadniając niczym takiego posunięcia. W gruncie rzeczy cały model tradycji wzorowany jest na katolicyzmie, co zwrotnie sprawia, że katolicyzm wydaje się najdoskonalszym wcieleniem tradycji. Brakuje też przykładów tradycji świeckich oraz opisu związku religii z tradycją. Oczywiście, nie da się pomieścić wszystkiego w jednej książce, niemniej wątki te mogłyby zostać rozwinięte.

Zaskakiwać może również sam rezultat badań, który, wbrew intencji Grada, dostarcza argumentów przeciwnikom tradycji. Nierzadko można spotkać się z zarzutem, że w przestrzeni publicznej nie ma miejsca dla tradycji, ponieważ formułowane przez nią argumenty nie są zrozumiałe dla wszystkich uczestników debaty. Autor potwierdza tę obawę i stwierdza, że jedynym celem przedstawicieli tradycji w sferze publicznej jest przekonanie innych do konwersji i ekspansja danej tradycji. Na pochwałę zasługuje tu uczciwość intelektualna, niemniej wniosek ten nie jest moim zdaniem przekonujący. Modelowanie sporu politycznego na wzór debaty akademickiej wydaje się wręcz naiwne. Choć oczywiście przestrzeń polityki i przestrzeń uniwersytetu przenikają się, to jednak przyjęcie maksymalizacji potencjału racjonalności jako zasady rządzącej sporem politycznym domaga się uzasadnienia, którego w książce brakuje.

Mimo tych kilku wątpliwości książka O pojęciu tradycji zasługuje na uwagę i polecenie. Pytanie o możliwość ortopraksji we współczesnych społeczeństwach Zachodu jest pytaniem dobrze postawionym. Trudno nie zgodzić się z diagnozą autora, że nowoczesność jest wroga tradycji i jej zagraża. Oczywiście twierdzenie, że życie bez tradycji, to życie nagie i bez formy jest sformułowane nieco na wyrost, niemniej warto rozważyć, czy rzeczywiście nie mamy do czynienia ze strata, odwracając się od tradycyjnych praktyk.

Jakub Gużyński

Uniwersytet Mikołaja Kopernika e-mail: guzynski@protonmail.com 